Influencing and Promoting Global Peace and Security Horion minghts

Quarterly Journal by Beyond the Horizon ISSG - Volume 3 Issue 3

\title{
Reintegration of ISIS Returnees: A Myth or Reality?
}

Onur Sultan, Emanuela Biffi, Pilar Cebrián

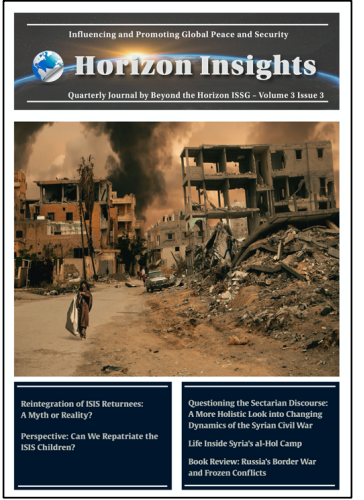

To cite this article:

Sultan, O., Biffi, E. \& Cebrián, P. (2020). Reintegration of ISIS Returnees: A Myth or Reality? Horizon Insights, 3(3), 1-16. https://doi.org/10.31175/hi.2020.03.01

$\Rightarrow$ For the link to this issue of the journal

https://behorizon.org/wp-content/uploads/2020/10/Horizon-Insights-2020-3.pdf

Horizon Insights Journal Homepage: https://behorizon.org/horizon-insights/

ISSN: 2593-3582 (printed), 2593-3590 (online)

Submit your article 
Onur Sultan ${ }^{1}$, Emanuela Biffi², Pilar Cebrián ${ }^{3}$

\begin{abstract}
The returnees, their repatriation and measures to be taken to ascertain their reintegration into their home countries attract the attention of scholars, politicians and general public. Despite current wide public aversion, it is estimated that nationals of the member states currently filling prisons and camps in North and East Syria will be repatriated due to internal and external pressures in the near future. This article aims to inform policy makers and relevant authorities on the latest situation regarding current and potential future returnees and explore the role of restorative justice for their reintegration to their home countries alongside existing approaches. The article ends by an array of policy recommendations of the authors.
\end{abstract}

Keywords: Restorative justice, ISIS, foreign terrorist fighter, FTF, returnee, reintegration, rehabilitation, support circle

\title{
Introduction
}

The issue of returning fighters that has become subject of so much political debate has already taken place in trickles and waves since 2013. About one third of those who have travelled to war zone to join various groups like ISIS (Islamic State of Iraq and the Levant) or al-Nusra have already returned to their home countries in Europe. In the meanwhile, thousands of captured ISIS fighters and their families currently fill overcrowded, crumbling, makeshift prisons or camps in Syria (Seldin, 2019). On top of the limited Kurdish capacity to guard and look after so many prisoners, there is also risk of collapse of the Kurdish administration in the North and East of Syria.

On 9 October 2019, Turkish troops conducted cross-border operations to create a $30 \mathrm{~km}$-deep safezone within the country. As a result of this Turkish offensive, more than 800 ISIS detainees (Islamic State of Iraq and Syria), escaped (Turak, 2019). The collapse of the Kurdish autonomous region due to Turkish incursions and -as a by-product the escape of ISIS detainees, guarded by Syrian Democratic Forces (SDF), is a scenario considered within range of possibility. Besides, Turkey has also started to deport captured foreign fighters to their home countries, including Europe. In an interview, Turkish minister of interior Soylu said, Turkey deported 780 out of more than 1000 foreign terrorist fighters (FTFs) to their countries of origin in 2019 (Daily Sabah with AA, 2020). This comes as an addition to 430 FTFs deported to France, UK, Germany and Spain before 2019.4 This massive exodus back may overwhelm the response system in their home countries and it could be used by extreme-right populist parties as a tool to bolster their position in the political system.

In February 2019, the US President Trump made a call to EU to take back the 800 European ISIS fighters captured by US forces in Syria and Iraq, and put them on trial (Wintour, 2019). The US is the leading state of the Global Coalition against ISIS and has been in charge of funding the prisons renovations and other inmates' expenses. ${ }^{5}$ It is not possible to say the EU has responded positively to this call. The main

\footnotetext{
1 Onur Sultan is senior research fellow and project coordinator at Beyond the Horizon International Strategic Studies Group (www.behorizon. org). In this article, he contributed with the overview of the current problem of returnees in Europe and existing approaches to their reintegration.

2 Emanuela Biffi is a project officer at the European Forum for Restorative Justice (www.euforumrj.org). Among others, she follows the EFRJ initiatives in relation to violent extremism, radicalization, hate crime and polarization. In this article, she contributed with the reflections on the potential of restorative justice for the reintegration of returnees.

3 Pilar Cebrián is an investigative journalist who has conducted interviews to 26 European-born ISIS members jailed in Syria and Iraq (she's the only foreign researcher who got access in Baghdad). The research is funded by BBVA (Leonardo Grants 2018) and will be published in a book in 2021. Cebrián is a Middle East/War reporter based in Istanbul for ATresMedia Spanish network.

4 This figure was given by the Ministry of Foreign Affairs in Turkey to the third author, Pilar Cebrián.

5 According to the Global Coalition spokesperson, Col. Sean Ryan, the US had donated \$1.6 millions for the rehabilitation of northern Syria prisons in order them to meet international standards.
} 
European rationale is that this battle-hardened group trained with weapons and holding extremist views could radicalize European youth or carry out new attacks. The root causes for such fear include political risks connected to the public aversion for the returns, ${ }^{6}$ security risks associated with not accurately understanding the real motivations behind returns, and finally incapacity to monitor and prosecute returnees due to relatively lenient criminal laws effective in Europe.

\section{Efforts to Block / Delay Returns}

In February 2020, Syrian Kurds stated they would hold trials for 1000 male and 4000 female Islamic State fighters from 50 countries. This came after failure to agree on if and how they would be repatriated to their home countries to face justice or setup of an internationally recognized tribunal (Sabbagh, 2020). A leaked draft agreement between the Kurds and the EU foresaw among other items the following:

a. Separation of the women based on their radicalization level and level of faithfulness to ISIS within Al-Hol Camp.

b. Immediate set-up of schools to separate children from mothers during daytime and -if possible- during night through boarding schools to prevent radicalization.

c. Categorization of the women as:

(1) Those who have been dragged there under pressure and have "shown themselves innocent", and

(2) Those who have knowingly joined the terrorist group.

d. Rapid repatriation of women in the first category to their home countries without delay "in consultation with their country".

e. Trial of the second group together with men through local courts that would not deliver death penalty, but would punish those:

(1) who committed the worst atrocities with 15 years to life imprisonment, and

(2) who can only be accused of membership of IS with up to four years in prison.

f. Repatriation of those convicted also "after a period of time and in good conduct" (Vlierden, 2020)

It is unlikely that European foreign fighters and their families will be tried in local courts for many reasons. The primary reason is that SDF is not a state actor recognized by European member states. Especially considering the Turkish stance vis-à-vis Kurdish administration and the fact that Turkey is a NATO member taking role in the Coalition, such finality becomes even more elusive. More importantly, SDF does not have capacity to try them with Western standards. Lawyer André Seebregts who has witnessed the trials of many of the women articulates his concerns as: "I was there myself at the court last summer and no trial can now be conducted by our standards. There is no question of hearing witnesses or assistance from a lawyer. In fifteen minutes, a case is ready and tried" (Rosman, 2020).

It is also difficult to really differentiate those who are die-hard ISIS fanatics and those who have "shown themselves innocent". A recent article by Vera Miranova shows how economic and social dynamics take over in defining the behavior of the women in camps. As ISIS supporters send money to those still holding fast to the group and its ideology, many women in camps pretend to be aligned with the ideology, enforcing ISIS moral code in the camp or in online chat groups to receive supporter money

\footnotetext{
6 The European public opinion is generally against repatriations or return of foreign fighters and their family members. For example, an online survey conducted on 27 and 28 February 2019 by Odoxa-Dentsu Consulting for Le Figaro and France Info with involvement of 1001 French nationals at the age of 18 and above shows, $82 \%$ of the respondents approve prosecution of the jihadis in Iraq even though they risk receiving death penalty. The French public is against any kind of return including that of children. For the latter, $33 \%$ of respondents wants the maximum effort to be done to bring back the children whereas 67 \% wants Iraq and Syria take care of them. In the words of the authors of the survey, "Faced with the perceived risks, the main principles of law, freedom and even the issue of the death penalty do not weigh heavily in the balance for our fellow citizens [French society]" (Leclerc, 2019). In Norway, the repatriation of one woman with two of her children caused Norway's anti-immigration Progress Party (right-wing, populist) to leave Prime Minister Erna Solberg's coalition after six years and two months being part of it. The party argued the risk of allowing a person linked to ISIS into Norway outweighs the country's humanitarian duty to help the child (AFP, 2020).
} 
(2020). The question is how to differentiate who is real and who is a pretender before reaching a sound judgement or implementing a return program.

\section{The Size of the Target Groups}

During the retreat and fall of ISIS, people living under ISIS controlled areas, as well as families and children of ISIS members, were relocated to two refugee and IDP camps (Internally Displaced Persons) in Northeastern Syria, namely Al-Hawl (also spelled as Hol) and Roj. A good understanding on the number of European detainees in those camps will shed light on the size of the problem.

The Al-Hawl camp is located in the east of Hassakah, close to the Iraq-Syria border. As of May 2019, the camp accommodated 73.000 residents of which 11.000 were neither Iraqi nor Syrian. Between December 2018 and March 2019, all those captured were primarily brought to this camp, except for men above 14-15 years old. Also, the men released from SDF controlled prisons were allowed to join their families. The camp is currently divided into three parts. The first two parts have been allocated to Syrian and Iraqi nationals whereas a fenced third part hosts third party nationals including those of US and Europe (Saad, 2020). The camp has intermittently received massive media coverage featuring women bullying those not living up to the ISIS ideology under the terror group's rule and attacking guards. More recently the camp has been subject to public discussion after the death of 8 children under five due to malnutrition, and poor health and sanitary conditions (UN, 2020).

Unfortunately, there are no exact figures on the number of ISIS linked family members in Al-Hawl camp. But, the camp is currently estimated to hold approximately $\mathbf{6 8 . 0 0 0}$ individuals (Saad, 2020). A recent UN report estimates the number of children as $\mathbf{4 5 . 0 0 0}$ including those born as result of rape. Within the total, $\mathbf{2 8 . 0 0 0}$ are children of foreign fighters from more than 60 countries of whom $\mathbf{2 0 . 0 0 0}$ are from Iraq. (The Independent International Commission of Inquiry on the Syrian Arab Republic, 2020)

UNICEF Executive Director Henrietta Fore states: “Children in Al Hol, like all children affected by conflict, have the right to humanitarian assistance. Those born to foreign nationals have the right to be safeguarded, including with legal documentation, family reunification and repatriation to their home countries when it is in their best interest" (UN, 2020). The number of foreign women and children (neither Iraqi nor Syrian) within the camp is approximately 10.000. 2500 of them should be transferred to Roj camp when the construction of new shelters is finished. The expansion of the Al-Hawl camp is also planned (RIC, 2020).

The camp Roj currently hosts $\mathbf{1 7 0 0}$ ISIS family members and children of whom $\mathbf{1 2 0 0}$ are foreigners (International Crisis Group, 2020). The camp, with the capacity of 470 shelters, is currently under costruction to add some 400 shelters to its capacity (OCHA, 2020). It came under spotlights after a British national, Shamima Begum made an interview with a journalist that resulted in stripping away of her nationality. Due to what happened to her, current residents of the camp are unwilling to give statements to journalists (Moaveni, 2019). About 2000 "less radicalized" women and their children are currently being transferred to this camp from Al-Hawl (Omar, 2020). The main difference between camp Roj and Al-Hawl is that the former is home to more modern looking women that openly reject ISIS. Here, $100 \%$ of those in the camp have been identified, interrogated and photographed, and women are not allowed to wear black colour, cover their face and chant ISIS slogans. The camp also has an education facility with limited capacity.

If the figures mentioned above are put together, a rough estimation can be made that 11.200 ISIS foreign fighter families and children currently fill special compartments in Al-Hawl and Roj camps. Save the Children estimates that until 13 October 2019, there were $\mathbf{8 . 7 0 4}$ children of foreign origin of whom 85\% were under age of 12 and $45 \%$ (4400) were under age of 5 (Save the Children, 2019). This figure roughly matches UN figures. As regards children of European origin, in November 2019, UNHCR human rights official Marie-Dominique Parent told the European Parliament that roughly 700 to 750 children with European links persisted in camps in the north and east of Syria, some 300 of them being French 
(France 24, 2020).

\section{Disengagement, Deradicalisation, Rehabilitation}

An important element of repatriations - if it happens- is to find ways to disengage / deradicalize the returnees and reintegrate them to their home countries. Member States, based on their historical, societal and local context, have tried to create structures that will work to that end, each with its own character. The programs are still in evolution, getting media coverage from time to time due to their successes (The Media Line Staff, 2020) or failures (Jacinto, 2017). In December 2019, the issue became a focal point for public scrutiny because of the London bridge attack involving a released terrorist offender who stabbed two participants at a conference on criminal rehabilitation in London (Shaw, 2019). The perpetrator, Usman Khan had participated in two rehabilitation schemes before release. Immediately after the event, the British government published recidivism rates of terrorist offenders to vent off public pressure. Accordingly, between January 2013 and December 2019 (7 years), 196 prisoners had been released in England and Wales and 7 were convicted again for terrorism-related offences, bringing the rate of recidivism to 3,6\% (Silke \& Morrison, 2020).

In continental Europe, two similar statistics should be mentioned to enable better comparison. The first one belonging to 189 individuals supervised by 'team TER' (Terrorism, Extremism and Radicalization) under probation in the Netherlands between 2012-2018 shows 11 re-offended. Of the offenses, only 8 were terrorism-related. If we omit non-terror related 3 re-offenses, the rate of re-offense among terror-related crimes is 4,23\%. A similar survey in Belgium on 557 perpetrators of jihadi related offences between $1990-2019$ shows a modest $2,3 \%$ recidivism rate with only 13 re-offenders (Silke \& Morrison, 2020). When compared with other crime types, the recidivism rate for terror-related crimes is extremely low: for example, in the Netherlands, the average recidivism rate for other crime types is $45-46 \%$.

In all cases, current and future returnees will be one day released from prison. A recent study by Globalsec that uses open source data over 199 terrorism convicts from 11 EU countries (including returnees) indicates 113 (57\%) of them will be released from prison by the end of 2023 (Rekawek, Szucs, Babíková, \& Hamel, 2019). For some countries like Belgium the situation is critical as most returnees will be released in 2020 as a result of general practice of 5 years sentences (Renard, et al., 2018). For the overall population of the returnees, there is no publicly available statistics.

\section{Is rehabilitation possible?}

To start with, there is need for greater understanding on which push and pull factors influenced a person to make the journey to a warzone, leaving their families and friends behind. This relates to better understanding different human needs and requires analysis on a case-by-case basis for the formulation of a strategy for rehabilitation. Each individual grows and interacts in a specific context and the root causes or motivators relevant for his or her decision to join terrorist groups should be well understood and addressed, while new ones are not created. ISIS as well as others of its like use an unchanging linear three-step narrative to incite the youth to join their ranks (see figure below).

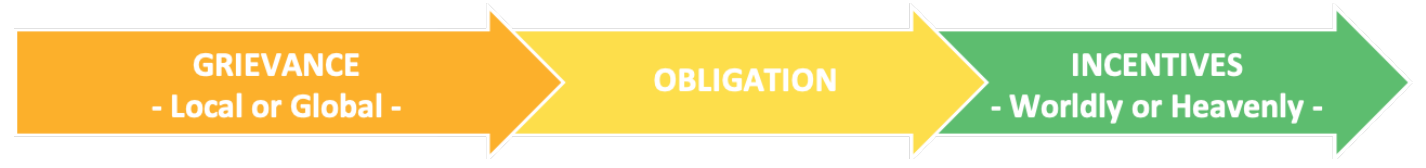

The dominant narratives indicate that terrorist groups initially elevate the target audience emotionally by exaggerating real or perceived grievances or creating new ones. Then the effort is directed to convince the audience that it is incumbent on him / her to contribute to efforts to build a caliphate/ Islamic state. In the final stage, the audience is convinced that he / she will get worldly / heavenly gains upon joining the advertised terrorist organization. 
The audience attributes different values to the three different steps in the mechanism and there might be changes in the order. A research including semi structured interviews with 63 ISIS defectors by Speckhard et al. shows how different contexts create different motivations among target groups. Among 63 interviewees, for 33 Syrians two main transversal motivators have been reported as the desire to join the uprising against Assad and the heavy coercion from ISIS. For Syrian militia members, the primary motivators were the fact that ISIS was more successful and better equipped on the battlefield than other jihadi groups. Young respondents have reported that the promise of unheard salaries, marriages and cars were extremely stimulating. For the locals in the towns that fell under ISIS control, the main motivator was the fact that not joining meant suffering, targeted for punishments and potential starvation. For the Westerners, "offers of a real salary, arranged marriages, sex slaves for men, traditional living for women, free housing and other amenities, along with the honors bestowed by ISIS on foreign fighters who come to Syria and Iraq were real attractions as many felt their lives to be lacking dignity, purpose, significance, and honor." (2018, p. 7)

Redouan Safdi, an imam that is involved in the deradicalization of FTFs alongside home-grown terrorists and radicals in a Belgian prison designed for terrorist offenders says : "When dealing with such a person, trying to start a deradicalization program, the first question I would always ask is, 'Why did this person go?"' During his inquiries into the real causes for travels, Safdi says: "They would usually start talking about that they have love for Islam, they want to live in an Islamic state, they want to live somewhere where shariah is implemented. When you go deeper with them in the conversation, when conversations are more meaningful, I would hardly hear them speak about Islamic state or the implementation of shariah. All I would hear is the injustices they have experienced in the past: racism, discrimination, poverty, lack of opportunity. [...] The majority of them are very young people. Many of them haven't even reached the age of 18. They are frustrated, alienated socially. Young people who are in search of identity, a meaning in life. Young people that did not feel at home in their own countries where they were born, who felt they were not appreciated" (Safdi, 2020)

Along the same lines, in an interview conducted by the first author, Onur Sultan, with a social worker in Brussels, the interviewee said: "In each case we see a person making the travel to Syria and Iraq, if we scratch the surface [if we delve deeper into the issue], we find a familial, social or economic problem. The perceived urgency or greatness of that problem pushes the person to think if he goes, he will have a better life there and leave that problem behind."

When asked about if he thinks rehabilitation and reintegration of returnees is possible, the imam Safdi says for a great number of them it is possible depending on only one condition. He says: "We have to be able and we have to be ready to listen to these people." He continues: "By listening I mean we have to get rid of racism, discrimination. We have to give these people a feeling that they are wanted, they are needed. We have to make sure these people feel at home. But this is the one thing that nobody is ready to do."

Another interview with an exit worker in Ghent verifies what Safdi says. He told the first author that one of the inmates in the prison was extremely touched by a letter from his secondary school teacher addressed to him and totally changed his views towards others. He continued: "However petty and simplistic it might seem, small gestures from time to time that shows they are cared for and respected creates great changes in their behaviors" (Safdi, 2020).

So, although a positive attitude respecting the dignity of the person nearly always creates impact, there is need for understanding the real motivators for each individual. This is a key-message when considering any type of intervention (restorative, rehabilitative, etc.) as a response to any type of criminal behavior.

\section{Testimonies from European jihadists}

The neo-jihadis or the new jihadi generation meet different criteria than the fighters in previous jihadi battlefields. The foreigner combatants within the mujahideen (mainly from Arab countries, Pakistan or Afghanistan), who were against the Soviet invasion in Afghanistan in the the 80s, responded to the 
Abdullah Azzam's fatwa forcing every muslim to wage jihad. They were insurgents immersed in Salafi-jihadist or Wahhabi circles. This evolved into a less romantic and more corporative fight in Iraq, after the 2003 American-led invasion. Few westerners filled the jihadi ranks but they were knowledgeable in jihadi theology. This purist profile changed in 2011 onwards. The new generation of jihadis are theologically ignorants that use religion as a pretext to rebel against injustice or to escape the path of failure. The majority of Europeans who traveled to the so-called caliphate are millennials (born in 1981-1993 and grown up amidst economic instability, armed conflicts and the emergence of the Internet). They were vulnerable to a more visual and low elaborated narrative shared in social media that impelled an express radicalization process (sometimes one year or less). The fact that being part of a terrorist group materialised due to their failures rather than their ambitions, is an indicator that returnees rehabilitation is achievable. The establishment of an Islamic State, and their society, was never their raison d'être, but a tool to get a second opportunity or rise against the system. If they can be given a hope or clear path for success in their home countries, rehabilitation can be possible.

"I wanted to enrol in the army that defends muslims, cause no armed forces safeguard muslim interests in the world. When Gaza is being bombed by Israel, who defends Palestinians?; when Syrians are being bombed by Assad, who goes to protect them?", asks rhetorically the Belgian ISIS prisoner Tarik Jadaoun, who fought alongside the terrorist group in Kobane, Deir ezzor, Baiji and Mosul. Jadaoun was eventually sentenced to death by Rusafa court in Baghdad in may 2018. Paradoxically, most of European-born ISIS recruits migrated to the caliphate in the seek for justice. Their perception is that Muslims are being oppressed by world powers, like foreign intervention in the Middle East conflicts, and they conclude the same for Europe. They think Europe is in war against Islam, and there is no place for their values and traditions in the public sphere. "The wear of hijab was forbidden in school, and it's part of our identity”, recalls the Belgian ISIS hisbah (religious police) member Bilal al-Marchohi, sentenced to the death in Baghdad in March 2019. The Antwerp-born prisoner was raised in the paradigmatic Borgerhout neighbourhood, who became the Belgian front between police and migrants descendants after Sharia4Belgium gained popularity in 2010. He was early politicized, even as a minor attended pro-Palestinian demonstrations or a public debate on the hijab with the Minister of Education.

Many citizens in these areas of Belgium, like Borgerhout (Antwerp), Verviers or Vilvoorde -where 29 youngsters joined the fight in Syria- complain that Muslim discrimination is systematic. Neighbours agree that access to labor market is limited, and they can't get high qualified positions. "My father came to Belgium as an engineer. But he was only accepted to clean trains at night for a very low salary. We grew up seeing my father at home the whole day, almost depressed because he never achieved his goals", says Elias T., a returnee from Vilvoorde, Belgium, who came back in 2013 after several months in Majlis Shura al-Mujahideen, a Syrian Jihadi brigade.

"Every muslim dreams with the idea of living in an Islamic state, in a real Islamic state. For me, coming here has been my great opportunity", states German Lamia K., the first European woman sentenced to death in Iraq for ISIS membership; although the verdict was commuted for life in prison after the appeal process. Lamia, a 52-year-old woman of Moroccan descent, refers to the valuable significance of the migration in Islamic theology, the hijrah; a concept that has been profoundly manipulated by the ISIS media department. Hadiths and quranic verses have been chopped or transformed and publicized for the terrorist group political interests in the propaganda platforms. The theological status of ISIS publications triggered thousands of Europeans to move to Syria and Iraq. Lamia was in charge of her disabled daughter so she'd spend hours at home and suffered from loneliness and depression. That is what brought her to an online chat room to socialise. Nevertheless she ended up in jihadi rooms and, according to German intelligence files, she recruited dozens of people via Paltalk.

"We were very ignorant, very stupid. We didn't have any knowledge of Islamic science", says Caner Cankurtaran, an ISIS Belgian combatant jailed in northeastern Syria, "we didn't have any base of Islam. Why? Because our parents never brought us to the mosque. I didn't know how to pray. I only knew I couldn't drink any alcohol or eat any pork meat. Then I started learning, but I did it in an extreme way, and that's not right". Cankurtaran refers to the fact that his generation has turned to religion looking 
for answers to their failed integration in European society. Their parents or grandparents migrated to Western European countries and spent their time concentrated in their jobs; however their sons still felt different from their classmates (mainly because of their name or skin colour). In the search of an explanation they turned to religion which was perceived as the differentiator. But the radical discourse was filling the vacuum of a unified Islamic narrative in Europe. Therefore radical individuals linked to Al Qaeda or ISIS got the mosques leadership and taught a vision of islam that opposes western values. "When I was in Brussels I'd hear that we had to leave Europe as soon as possible because we couldn't stay there", says Cankurtaran, "the same way 'You can't live seeing the fire set by infidels", he concludes quoting a hadith given by ISIS.

While identity, discrimination and deprivation are common drivers in Muslim-background radicalization, for ISIS converts, who constitute $23 \%$ of the interviewees, ${ }^{7}$ the individual and the family dimension play a stronger role. Many European teenagers took part in the ISIS proto-state, as the jihadi brides: many underage girls moved to the caliphate to marry a jihadi combatant. In this case, embarking on a journey to Syria was conceived as an act of rebellion against the parenthood and the school. Linda Wenzel, the German minor who travelled to Syria at the age of 16, was being bullied at school and suffered from relationship difficulties with her mother. The violence broadcasted during the Paris attacks in November 2015 was a catalyst for her radicalization. "I asked my mother, 'why do they do this?' This is one of the reasons I started researching (on ISIS) in Facebook (...) The first thing I liked is that I wouldn't have to smoke (as her classmates were doing) and I wouldn't cut my self anymore". She firstly converted and then left to Syria in a timeframe of seven months.

Sometimes the family history has influenced one member to turn into jihadi radicalization, as was the case of the French ISIS member Léonard Lopez. He's the descendant of a Polish Jew massacred in the Auschwitz concentration camp, and of a Spanish anarchist exiled to Algeria. Along the years, the concept of war losers passed on to the next generations. Lopez converted to Islam at the age of 17 and he crystallised the hunger for justice and victory. In most of the interviewees' families, common elements re-occur: migration, exile and war. Many of them are descendants of migrants who traveled to Europe in order to escape violence, repression or scarcity. But others, as it's the case of Léonard Lopez, have grown up in a family that was hit by the big war events of the 20th century.

This shows the importance of dialogue, understanding and efforts to 'close bounds' after a conflict has ended. Restorative justice introduces a new tool for the society to be able to move forward and close a chapter, in this case the ISIS caliphate and its resonance in Europe with dozens of terrorist attacks. Restorative justice offers an important practice to apply justice, take responsibility, show solidarity, speak about different truths and prevent that resentment, revenge, humiliation that are inherited by next generations, averting these future generations of further harm.

\section{Restorative Justice: Can it be a solution?}

As mentioned above, there are some main fears, risks and considerations behind the issue of foreign fighters' return in Europe: the strong public opinion fearing returns in local communities; the criminal justice and security responses often incapable to understand and tackle the root causes of radicalized behaviors; and the ethical considerations of proposing justice responses in line with the core democratic values of our societies. Despite the specificity of the case of returnees, these fears, risks and considerations are not much different from the responses given to other types of serious (but ordinary) crimes. Based on these core concerns, in the 1980s' Europe, a group of academics and practitioners started to challenge the "traditional" criminal justice system, defining restorative justice as a set of values and practice principles for victims to be heard and for offenders to take responsibility over the harm done.

\footnotetext{
7 Pilar Cebrián's research shows 6 out of 26 interviewees are muslim converts.
} 
Restorative justice is based on these generally accepted assumptions:

- Crime is a consequence of certain social conditions and broken relationships.

- Communities are responsible for removing or at least reducing those social conditions leading to crime.

- The consequences of crime have a societal and an individual dimension.

Restorative justice adopts different communication practice models (e.g. victim offender mediation, restorative circles, conferences, etc.) to tailor the justice process to individual cases and needs. Its goal is "addressing harm or the risk of harm through engaging all those affected in coming to a common understanding and agreement on how the harm or wrongdoing can be repaired and justice achieved" (European Forum for Restorative Justice, 2018). This definition, focusing on the main outcomes instead of on different practice models, has been the result of a movement that attempts to bring restorative justice values and practice principles beyond its implementation in the criminal justice system. Indeed, in recent years its areas of implementation grew as a response to conflicts in schools, workplaces, neighbourhoods and communities.

It is exactly this wider expansion of its scope that makes restorative justice highly relevant to returns of foreign fighters. Restorative justice presents opportunities at different stages of the criminal procedure (pre-, during and post-sentence) for returnees but also for their families, communities of belonging and new hosting communities. In practice, it proposes interventions that are interactive, participatory, tailor-made, open ended, and non-directive. This goes beyond the mere risk assessment oriented approaches usually adopted with returnees; the focus on establishing relationships and constructive interactions with different affected groups has proven to support processes of de-radicalisation, disengagement, desistance, and reintegration (RAN, 2020). The table below is an adaptation of the findings with politically motivated prisoners in Northern Ireland (Chapman, 2018) and more generally with cases of violent extremism, intergroup conflicts, hate crime and polarization, as there is no research yet on the use of restorative justice with returnees.

\begin{tabular}{|c|c|c|}
\hline $\begin{array}{l}\text { Specificities of cases involving } \\
\text { returnees }\end{array}$ & $\begin{array}{l}\text { Opportunities for restorative } \\
\text { justice }\end{array}$ & Difficulties and challenges \\
\hline $\begin{array}{l}\text { Returnees belonged to a "wider } \\
\text { offender community" that sup- } \\
\text { ported their beliefs and actions, } \\
\text { strengthening loyalty, commit- } \\
\text { ment, and solidarity with the } \\
\text { group. }\end{array}$ & \multirow[t]{2}{*}{$\begin{array}{l}\text { Practices including the wider } \\
\text { community (e.g. restorative cir- } \\
\text { cles) are preferred in cases of po- } \\
\text { larisation and intergroup conflict, } \\
\text { thus they are relevant also for the } \\
\text { reintegration of returnees. }\end{array}$} & $\begin{array}{l}\text { Returnees may deny the individ- } \\
\text { ual responsibility for their violent } \\
\text { actions. }\end{array}$ \\
\hline $\begin{array}{l}\text { Their victims are considered en- } \\
\text { emies belonging to a "wider tar- } \\
\text { geted community". }\end{array}$ & & $\begin{array}{l}\text { Returnees may not recognize } \\
\text { their victims as they are targeted } \\
\text { enemies of the cause. }\end{array}$ \\
\hline $\begin{array}{l}\text { Returnees may not identify with } \\
\text { the label "offender", while the } \\
\text { wider community may keep on } \\
\text { dehumanizing them (not consid- } \\
\text { ering them as human beings). }\end{array}$ & $\begin{array}{l}\text { Restorative justice practices avoid } \\
\text { labels such as "victims/ offend- } \\
\text { ers" to look at the many more } \\
\text { experiences that identify and de- } \\
\text { fine an individual. Also, the core } \\
\text { values of restorative justice (e.g. } \\
\text { respect, inclusion and mutual } \\
\text { understanding) can support re- } \\
\text { turnees and communities at large } \\
\text { in changing their opinions and } \\
\text { consequent biases. }\end{array}$ & $\begin{array}{l}\text { The public opinion and local } \\
\text { communities may insist on see- } \\
\text { ing returnees only through the } \\
\text { lenses of their past experiences. }\end{array}$ \\
\hline
\end{tabular}




\begin{tabular}{|c|c|c|}
\hline $\begin{array}{l}\text { Specificities of cases involving } \\
\text { returnees }\end{array}$ & $\begin{array}{l}\text { Opportunities for restorative } \\
\text { justice }\end{array}$ & Difficulties and challenges \\
\hline $\begin{array}{l}\text { Returnees may have suffered vic- } \\
\text { timisation experiences (e.g. be- } \\
\text { fore entering the terrorist group, } \\
\text { or in the camp, or in prison, or } \\
\text { discriminations during the rein- } \\
\text { tegration process) and they may } \\
\text { be reluctant to report the offence } \\
\text { to the police, fearing revenge or } \\
\text { disbelief. }\end{array}$ & $\begin{array}{l}\text { Restorative justice practices be- } \\
\text { yond criminal proceedings have } \\
\text { much potential because they } \\
\text { permit a tailor-made approach to } \\
\text { justice for these types of victimi- } \\
\text { sation experiences. }\end{array}$ & $\begin{array}{l}\text { Returnees may have an antago- } \\
\text { nistic stance to authorities, not } \\
\text { accepting to participate in a pro- } \\
\text { gramme delivered by the system } \\
\text { that they (and their community } \\
\text { of belonging) oppose. }\end{array}$ \\
\hline $\begin{array}{l}\text { Reparation for harm is not as } \\
\text { straightforward as in other type } \\
\text { of offences (e.g. crimes against } \\
\text { property). They may deny the } \\
\text { harm, because of a clear ideology } \\
\text { and strategy to support and jus- } \\
\text { tify their initiatives, violence and } \\
\text { harmful consequences, and they } \\
\text { are able to explain their views in } \\
\text { a clear and convincing tone. }\end{array}$ & $\begin{array}{l}\text { Creative solutions are needed to } \\
\text { prevent one of the parties to pre- } \\
\text { vail in the discussion and under- } \\
\text { standing of reparation and also to } \\
\text { find a suitable and long-lasting } \\
\text { action plan that tackles biases } \\
\text { and prejudices. }\end{array}$ & $\begin{array}{l}\text { Returnees may have difficulties } \\
\text { to understand the consequenc- } \\
\text { es of their actions if they really } \\
\text { believed in the values of the ter- } \\
\text { roirst group. }\end{array}$ \\
\hline \multirow{2}{*}{$\begin{array}{l}\text { Professionals often represent the } \\
\text { majority of the population (e.g. } \\
\text { white middle class) and they may } \\
\text { not reflect the vulnerabilities and } \\
\text { specific needs of minorities (e.g. } \\
\text { the Islamic community). }\end{array}$} & $\begin{array}{l}\text { Because of its tailored practices } \\
\text { and flexible practitioners, restor- } \\
\text { ative justice may reflect on these } \\
\text { types of systemic issues. }\end{array}$ & $\begin{array}{l}\text { Restorative justice services as } \\
\text { well as criminal justice agencies } \\
\text { must take this into account when } \\
\text { hiring new personnel. }\end{array}$ \\
\hline & $\begin{array}{l}\text { Restorative justice brings back } \\
\text { the conflict to the individuals in- } \\
\text { volved. }\end{array}$ & $\begin{array}{l}\text { The public opinion and mass } \\
\text { media communications, may in- } \\
\text { fluence the implementation of } \\
\text { restorative justice programmes in } \\
\text { cases involving returnees. }\end{array}$ \\
\hline
\end{tabular}

It is exactly this wider expansion of its scope that makes restorative justice highly relevant to returns of foreign fighters. Restorative justice presents opportunities at different stages of the criminal procedure (pre-, during and post-sentence) for returnees but also for their families, communities of belonging and new hosting communities. In practice, it proposes interventions that are interactive, participatory, tailor-made, open ended, and non-directive. This goes beyond the mere risk assessment oriented approaches usually adopted with returnees; the focus on establishing relationships and constructive interactions with different affected groups has proven to support processes of de-radicalisation, disengagement, desistance, and reintegration (RAN, 2020). The table below is an adaptation of the findings with politically motivated prisoners in Northern Ireland (Chapman, 2018) and more generally with cases of violent extremism, intergroup conflicts, hate crime and polarization, as there is no research yet on the use of restorative justice with returnees.

Some concrete restorative-focused tools have been already adopted for the re-entry planning and reintegration in society of incarcerated individuals who committed serious crimes and could be adopted also for cases involving returnees: 1) support circles, 2) mentoring interventions by formers, and 3) restorative training for exit workers.

Support circles are initiated to ensure that the person knows that he/she is cared for and also to make the supporting people aware of the person's needs. The Huikahi restorative circle developed in the Waiawa Correctional Facility in Hawaii and already adopted in de-radicalisation processes is a completely voluntary group dialogue process including the incarcerated individual, his/her family members and friends, and at least one prison representative (Pereira, 2019). This practice emphases five 
key restorative-oriented elements, proposed by the restorative facilitator (focus on strengths, responsibility, repair, reconciliation and action). The incarcerated individual and all participants are invited to list his/her achievements and strengths, to reflect on the people harmed by the offence (even if not present in the room) and to propose a concrete action plan to prepare to leave the prison. Similar practices have also been designed based on John Braithwaite's Reintegrative Shaming Theory (Braithwaite, 1989), where the community of care expresses disapproval and suffering for the act and still respect and affection for the person who did it. Another restorative-oriented tool is the Circles of Support and Accountability (COSA) model, designed for the reintegration of high-risk sex offenders into their communities. ${ }^{8}$ This model has been proven useful not only to support the ex-offender but also to prevent the stigmatization of the community, both objectives relevant also for returnees. COSA proposes two different groups, one with volunteers (the social network for those finding their way out of prison) and one with professionals (in case further support is needed). Circles are organised each week until needed, with one leading volunteer getting in touch more often with the ex-offender. In cases involving returnees, it would be important to include in the circle members of the Muslim and non-Muslim communities.

Mentoring interventions involving former offenders have also been integrated in some restorative-oriented processes in the aftermath of extreme violence. For example, politically motivated prisoners in Northern Ireland actively participated in the peacebuilding process of the country; among other restorative-oriented activities, about 80 of them have been trained in restorative justice practices by Ulster University, so that they could use these new skills in their communities, preventing further harm to occur. ${ }^{9}$ Similarly, former radicalized individuals became involved in local peacemaking initiatives for preventing young people to radicalize (e.g. Fighters for Peace in Lebanon, Codex Foundation in Poland) (RAN, 2020). Among other guidelines, in 2017 the Radicalisation Awareness Network referred to practices involving right-wing extremists to cooperate with Islamic extremists, and vice-versa, to support each other in the de-radicalisation process (RAN, 2017). For formers, this is an opportunity to show strengths and achievements, build connections, and restore their role as citizens in their community. For others, hearing about these concrete experiences give them the opportunity to image a future self. These mentoring interventions fulfill some of the key principles of restorative justice, such as empowerment, responsibility, solidarity, truth sharing and focus on the future. Because of the recentness of the issue, there are no concrete mentoring initiatives yet involving returnees.

Finally, it is crucial to train exit-workers, and other professionals working with radicalized groups, in restorative-focused skills (see deliverables of the EU-funded project Exit Europe). ${ }^{10}$ In practice, exit workers are required to reflect on how to engage with this target group with respect for their human dignity, to hear with an open mind to their different truths and acknowledge other levels of responsibilities (e.g. what societal issues brought them to enter the terrorist group and could have been done to prevent it) and to listen to personal narratives that can challenge their perception as "monsters". Also, they should be trained in techniques that promote empathy, active listening and behavioral change, such as Motivational Interviewing or Nonviolent Communication models, and must be aware of the existence of restorative justice practices and services that can involve the parties in a dialogue (e.g. mediations, circles), if needed.

These restorative-oriented tools for the reintegration of returnees in societies are to be integrated with an important work at the community level. Indeed, among other potential benefits, restorative justice programmes may lead to more effective crime prevention strategies (UN Office on Drugs and Crime, 2020). This is because the participatory process can help to identify underlying causes of crime and deviance and prepare tailor-made responses to prevent crime. Moreover, the process allows communities to be heard and share their concerns in the aftermath of crime and violence, advancing their active participation in the justice process and giving them a concrete role in supporting the parties directly affected. Through a series of recent, local, bottom-up initiatives, restorative practices are also used at

\footnotetext{
8 For more information, please consult https://www.circleseurope.eu.

9 For more information, please consult http://www.alternativeproject.eu/?s=northern+ireland.

${ }_{10}$ For more information, please consult https://cultures-interactive.de/en/exit-europe.html.
} 
community level to reduce conflict, improve relationships and support marginalised individuals in being part of the community (Mannozzi, 2019). The aim is to promote a community model focused on the well-being of its members, a vision extending beyond their mere inclusion and participation in community life. Indeed, focusing on the reintegration and rehabilitation of those who are socially excluded and marginalised (e.g. returnees) may not be sufficient, or even beneficial, for them and for the community's social cohesion. Instead, focusing on well-being means integrating individual beliefs and collective reactions in terms of one's life and capabilities (Lepri, Lodi, \& Patrizi, 2019). This is significant for preventing isolation and disconnection, triggers for extremist and hate-focused thoughts.

\section{Alternative costs of "no repatriation"}

According to a survey conducted by Pew Research Center in Spring 2017, ISIS was named as the top threat in a total of 18 countries among the total of 38 countries surveyed. The survey that asked about eight possible threats showed divergent level and focus of concern by region and country. Yet, ISIS (62\%) and closely following climate change $(61 \%)$ were the most frequently cited security risks by the interviewees (Pouchter \& Manevich , 2017). This explains the reason for public aversion to the repatriations. However, for the member states, leaving their citizens in Syria is fraught with multiple risks too.

First of all, camps and overcrowded prisons serve as pressure cooker where newer versions of terrorist organizations are cooked. Abu Ahmed (a pseudonym for an IS leader) says: "Without Camp Bucca, IS would never have existed. It was the factory that shaped us. We already had the time in the world to sit together and make plans". The prison was operated between 2003 and 2009 by US forces to detain Al Qaeda terrorists. Of the 25 most important ISIS leaders, at least 17 were detained in Iraq between 2004 and 2011 - and Camp Bucca had the greatest share among all others. (Vlierden, 2016). The prisons in South and East of Syria have potential to serve as a forum where new plans are made, international networks are built, and the basis of next terrorist group(s) is laid. The inmates have contacts with the terrorist organizations they belong to even in prison. For example, when asked about the contact with ISIS cadres hidden within Iraqi population, Tarik Jadaoun replied: "Yes, it's possible, it's easy, it can be done with the phone, but in different ways too. I share a cell with other Iraqi ISIS members, and some of them have just been released", meaning messages are sent outside.

ISIS detainees in prisons governed by SDF forces from time to time riot and escape. In 2020, inmates rioted and wrested control of several parts of the prisons in March (McKernan, 2020) and early May (AP, 2020). Among the 11 escapees, although 8 have been caught and brought back to the prison, 3 are still loose. As regards women and children, escapes do not necessarily require riots. While escapes from Camp Roj are extremely hard and rare, in al-Hawl, escapes take place on weekly basis (Snell, 2020). Those who escape find their ways to Idlib, where other jihadi organizations are in control, or to Turkey. They can easily find their ways back to their home countries with fake papers.

The conditions in the camps and especially in al-Hawl are extremely unhealthy and difficult. The foreign nationals in the camps constantly start petitions to the prison / camp authorities asking their countries to take their care (ICRC, 2019). Miranova reports that $\$ 300-500$ a month is barely enough for a mother with several children to survive in the camps. Besides, in the absence of schooling, the children are exposed to ISIS propaganda on continuous basis. There are occasions that unattended children have been smuggled out of the camp to go to Idlib to join other jihadi groups (Miranova, 2020).

Among 13.000 ISIS foreign fighters and family members, $\mathbf{9 0 0 0}$ of them are children and nearly half of the children are below 5 years of age. ICRC President Peter Maurer says: "Al Hol camp is no place for any child. No mother, or grandmother, should have to try to care for children in conditions like this" (ICRC, 2019). Their home countries have alongside the above-mentioned security considerations, ethical responsibility to repatriate them. When this feeling of abandonment and low education level combines, there is high risk that these individuals will combine forces against their countries of citizenship and create incentives for them to form new ranks of such groups.

The general discourse about returnees and actions towards them, their immediate and wider families 
create waves of communication that reach far beyond them. They have brothers, sisters, fathers, mothers, friends, people who care for them whatever belief or ideology they subscribe to. This means that whatever actions we take these are spread to wider circles in our societies; this refers to the decision to repatriate or not FTFs and their families, the treatment provided in prison and probation, the public discussion on the media, the type of assistance and support they receive from the state, the possibility to engage in a restorative-oriented process, etc. Any negative and uncostructive action, perceived or experience as an injustice, has the potential to break the bonds between these groups and the state, triggering a new wave of radicalisation and terrorism.

\section{Conclusions and Policy Recommendations}

The dire living conditions in the camps in Syria and Iraq, incompatibility / incongruence of judicial processes in both countries, external pressures from especially the US, and internal pressure from families and relatives of foreign fighters has pushed and will continue to push member states to repatriate their citizens. Since early phases in the evolution of the Syrian civil war, member states have made adaptations to their penal code alongside programs to rehabilitate / reintegrate returnees.

There is need to systematically investigate all interventions (judicial, penitentiary, post-penitentiary) in member states and beyond, focusing on successful and failed initiatives and offer do-able, evidence-based approaches adapted to the needs of the respective states. The research should fusion of excellent multi-disciplinary research (psychology, communications [as an important vector in informing policy making], criminology and victimology, humanities, sociology, etc.), field experience of law enforcement authorities/agencies and practitioners, and host society representatives to build conditions conducive to rehabilitation of current and future returnees.

Member states should not overlook risks of leaving their citizens in detainee camps and prisons in Syria and Iraq. Instead of abandoning them to an unknown fate, they should think about accelerating efforts to build up systems that will contribute to rehabilitation of those individuals.

Current penal codes, penitentiary and post-penitentiary systems in the member states should be well structured around rehabilitative philosophy rather than punitive one, that sees custodial segregation as a means to an end instead of an end by itself. Programs should listen to individual's problems and propose individualised plans for reintegration. These should include a mixture of psychological and religious counselling and educational support as a response to individual needs and interests. Competent personnel that has been well trained and have good communication skills (also in restorative-oriented practices) will certainly be the key for solution.

Defeating terrorist organizations militarily does not directly translate into their total defeat. As can be seen from the case of ISIS, such groups move across the range of "terrorist organization- insurgent group - proto-state". Total defeat only comes with its total bankruptcy in terms of reduced human resources and discredited ideology. This means member states should allocate more resources to better educate young at-risk groups so that they do not fall for extremist ideologies Special attention is needed for supporting juvenile offenders. The prison environment is a guarantee that a young inmate will go to worse; there is risk to fall into these jihadi networks due to either desperation or rebellion / search for protection. Defectors of jihadi groups are currently actively employed by countries like Germany, UK and Canada to warn those on the way of radicalization and the radicalized, to show fallacies of terrorist groups' claims and ideologies and to bring them to their senses on the harms they could give to themselves and to the society.

Member states authorities should be better equipped to evaluate the way Islamic religion is taught in mosques, schools (e.g. countries as the UK fund independent Muslim schools) or Muslim welfare centres. This is a sensitive subject since it can collude with constitutional principles as religious freedoms versus state interference; but past years show how Salafi jihadism and terrorist propaganda has filled this vacuum in European countries. A rigorous, accurate and moderate theology program that will educate imams and teachers on non-politicised Islam and its history should be established. Therefore, 
these positions would require a state certificate. "The Islam in Europe is mainly an immigrant's Islam", says Frank Hensch, an imam from Verviers, Belgium, a city where many youngsters joined ISIS. He says the Muslim community needs support from the state to dissociate culture and religion so new generations fully adopt the Belgian/western/European culture but continue living according to Islam.

In recent years, restorative justice has been proven to be effective within and beyond the criminal justice system, also to address serious and complex crimes and conflicts, such as violent extremism and polarisation. As shown in a literature review conducted by the European Forum for Restorative Justice (2017), participants (victims, offenders, their supporters and community members) are satisfied with the restorative process and its outcomes. The experience of restorative justice in cases of violent extremism cases is quite limited and even less is known concerning its potential with returnees. Still, based on other restorative justice experiences in serious crimes, it is possible to identify some practices (e.g. support circles, mentoring interventions, restorative training for exit workers) that can be useful to address this target group and the communities that will receive them. More (action) research is needed to further develop this area and identify the challenges and opportunities for using restorative justice approaches with foreign fighters returning in Europe. 


\section{Bibliography}

AP. (2020, June 29). Reports: IS prisoners riot in jail in northeast Syria. Retrieved August 2020, from AP News: https://apnews.com/article/7813f9ed5bef3b3627752bee445f2a07

AFP. (2020, January 20). Norway: Populist party quits government over jihadi spouse repatriation. Retrieved August 2020, from The Local no: https://www.thelocal.no/20200120/norways-populist-party-in-emergency-meeting-over-repatriation-of-isis-linked-woman

Braithwaite, J. (1989). Reintegrative Shaming. Retrieved from http://johnbraithwaite.com/wp-content/uploads/2016/05/2000_Reintegrative-Shaming.pdf

Chapman, Tim. ““'Nobody has ever asked me these questions”: Engaging restoratively with politically motivated prisoners in Northern Ireland." In Victims and Perpetrators of Terrorism: Exploring Identities, Roles and Narratives., by Orla Lynch and Javier (Eds) Argomaniz. London: Routledge, 2018.

Daily Sabah with AA. (2020, March 20). Turkey deports Daesh terrorist to Norway. Retrieved August 2020, from Daily Sabah: https://www.dailysabah.com/politics/war-on-terror/turkey-deports-daesh-terrorist-to-norway

European Forum for Restorative Justice. (2017). Effectiveness of restorative justice practices: An overview of empirical research on restorative justice practices in Europe. Retrieved from https://www.euforumrj.org/ sites/default/files/2019-11/a.2.7.-effectiveness-of-restorative-justice-practices-2017-efrj.pdf

France 24. (2020, January 17). UN says children of jihadists are in grave danger, calls for them to be repatriated from Syria. Retrieved August 2020, from France 24: https://www.france24.com/en/20200117-united-nations-jihadist-islamic-state-syria-refugees-repatriation

ICRC. (2019, March 22). Syria's Al Hol Camp: Families in Desperate Need. Retrieved September 2020, from ICRC Newsroom: https://www.icrcnewsroom.org/story/en/1870/syria-s-al-hol-camp-families-in-desperateneed

International Crisis Group. (2020). Women and Children First: Repatriating the Westerners Affiliated with ISIS. International Crisis Group. Brussels: International Crisis Group. Retrieved from International Crisis Group: https://www.crisisgroup.org/middle-east-north-africa/eastern-mediterranean/syria/208-women-and-children-first-repatriating-westerners-affiliated-isis

Jacinto, L. (2017, August 01). France's 'deradicalisation gravy train' runs out of steam. Retrieved 2020 April, from France 24: https://www.france24.com/en/20170801-france-jihad-deradicalisation-centre-closes-policy

Leclerc, J.-M. (2019, February 28). Les Français se prononcent massivement contre le retour des djihadistes. Retrieved August 2020, from Le Figaro: https://www.lefigaro.fr/actualite-france/2019/02/28/0101620190228ARTFIG00275-les-francais-se-prononcent-massivement-contre-le-retour-des-djihadistes.php

Lepri, G., Lodi, E., \& Patrizi, P. (2019). Tempio Pausania: social conflict resolution in a community setting. The International Journal of Restorative Justice, 2(2), 314-319.

MacCormick, A. (1950). The Prison's Role in Crime Prevention. Journal of Criminal Law and Criminology, 41(1), $36-48$

Mannozzi, G. (2019). The emergence of the idea of a 'restorative city' and its link to restorative justice. The International Journal of Restorative Justice(2), 288-292.

McKernan, B. (2020, March 30). Islamic State prisoners escape from Syrian jail after militants riot. Retrieved August 2020, from The Guardian: https://www.theguardian.com/world/2020/mar/30/islamic-state-prisoners-escape-from-syrian-jail-after-militants-riot

Miranova, V. (2020). Life inside Syria's al-Hol camp. Horizon Insights(3).

Moaveni, A. (2019, November 27). We must not abandon the women and children of Isis in camps in Syria. Retrieved 2020 September , from The Guardian: https://www.theguardian.com/commentisfree/2019/nov/27/ women-isis-syria-camps-refugees

OCHA. (2020, August 28). Syria - Roj Refugee / IDP Camp: Overview - As of June 2020. Retrieved September 2020, from Reliefweb: https://reliefweb.int/map/syrian-arab-republic/syria-roj-refugee-idp-camp-overview-june-2020

Omar, S. (2020, July 29). 'I'll never abandon you': the French fight to bring ISIS-linked women and kids home from Syria. Retrieved August 2020, from Rudaw: https://www.rudaw.net/english/world/29072020 
Pereira, A. (2019). Imagining a Restorative Approach to Individual Reintegration in the Context of (de)Radicalization. In G. Grandi \& S. Grigoletto, Restorative Approach and Social Innovation: From Theoretical Grounds to Sustainable Practices (pp. 61-81). Padova: Padova University Press.

Pouchter, J., \& Manevich , D. (2017, August 1). Globally, People Point to ISIS and Climate Change as Leading Security Threats. Retrieved March 2019, from Pew Research Center: https://www.pewresearch.org/global/2017/08/01/globally-people-point-to-isis-and-climate-change-as-leading-security-threats/

RAN- Radicalisation Awareness Network. (2017, June 27). Dos and don'ts of involving formers in PVE/CVE work. Retrieved June 2020, from RAN: https://ec.europa.eu/home-affairs/sites/homeaffairs/files/what-wedo/networks/radicalisation_awareness_network/ran-papers/docs/dos_and_donts_involving_formers_in_ pve_cve_work_bordeaux_27_06_2017_en.pdf

RAN - Radicalisation Awareness Network. (2020, January 14). The role of restorative justice in preventing and responding to violent extremism. Retrieved from RAN: https://ec.europa.eu/home-affairs/sites/homeaffairs/ files/what-we-do/networks/radicalisation_awareness_network/ran-papers/docs/ran_rvt-exit_role_of_restorative_justice_dublin_3-4_122019_en.pdf

Rekawek, K., Szucs, V., Babíková, M., \& Hamel, E. (2019). European Jihad: Future of the Past? From Criminals to the Terrorists and Back? Bratislava: Globsec.

Renard, T., Coolsaet, R., Heinke, D., Malet, D., Minks, S., Raudszus, J., \& van Ginkel, B. (2018). Returnees: Who are They, Why are They Coming Back and How Should We Deal with Them? . Brussels: Egmont.

RIC. (2020, May 21). Briefing: Coronavirus risks and preventative measures in Hol camp. Retrieved August 2020, from RIC: https://rojavainformationcenter.com/2020/05/briefing-coronavirus-risks-and-preventative-measures-in-hol-camp/

Rosman, C. (2020, February 07). Koerden willen buitenlandse IS'ers zelf berechten, minister Blok gaat met ze praten. Retrieved August 2020, from AD: https://www.ad.nl/binnenland/koerden-willen-buitenlandseis-ers-zelf-berechten-minister-blok-gaat-met-ze-praten a176da02/?referrer=https\%3A\%2F\%2Fwww.google. com\%2F

Saad, N. J. (2020). The Al Hol camp in Northeast Syria: health and humanitarian challenges. BMJ Global Health(5), 1-3.

Sabbagh, D. (2020, February 6). Syrian Kurds to put Isis fighters from dozens of countries on trial. Retrieved August 2020, from The Guardian: https://www.theguardian.com/world/2020/feb/06/syrian-kurds-to-putisis-fighters-from-dozens-of-countries-on-trial?CMP=share_btn_tw

Safdi, R. (2020, June 10). Can an ISIS Terrorist be Rehabilitated and Reintegrated into Society? Retrieved August 2020, from ICSVE: https://www.icsve.org/can-an-isis-terrorist-be-rehabilitated-and-reintegrated-into-society/

Save the Children. (2019, October 16). A Tiny Proportion of Foreign Children in North East Syria Camps Repatriated in 2019. Retrieved August 2020, from Save the Children: https://www.savethechildren.net/news/ tiny-proportion-foreign-children-north-east-syria-camps-repatriated-2019

Seldin, J. (2019, September 18). Makeshift Prisons for Islamic State Fighters Reaching Breaking Point. Retrieved 2020 September , from VOA: https://www.voanews.com/middle-east/makeshift-prisons-islamic-state-fighters-reaching-breaking-point

Snell, L. (2020, February 20). Escaped ISIS Detainees from Syria's al Hol Camp Allegedly Find Freedom in Turkey. Retrieved September 2020, from The Investigative Journal: https://investigativejournal.org/escapedisis-detainees-from-syrias-al-hol-camp-allegedly-find-freedom-in-turkey/

The Independent International Commission of Inquiry on the Syrian Arab Republic. (2020). They have erased the dreams of my children: children's rights in the Syrian Arab Republic. Geneva: UN.

Turak, N. (2019, October 14). Hundreds of ISIS prisoners are escaping from camps in northern Syria amid Turkish offensive. Retrieved September 2020, from CNBC: https://www.cnbc.com/2019/10/14/isis-prisonersare-escaping-from-camps-in-syria-amid-turkish-offensive.html

Vlierden, G. V. (2020, February 25). Koerden willen nu ook onze IS-vrouwen berechten: “Wie zich liet meeslepen mag meteen naar huis". Retrieved February 2020, from HLN: https://www.hln.be/de-krant/koerden-willen-nu-ook-onze-is-vrouwen-berechten-wie-zich-liet-meeslepen-mag-meteen-naar-huis a4c45275/

Vlierden, G. V. (2016, June 21). Camp Bucca, de gevangenis waar IS geboren is: kleinste garnaal stapt er buiten als volleerd terrorist. Retrieved August 2020, from HLN: https://www.hln.be/nieuws/camp-buccade-gevangenis-waar-is-geboren-is-kleinste-garnaal-stapt-er-buiten-als-volleerd-terrorist a8e34bfc/?ref- 
16 Onur Sultan, Emanuela Biffi, Pilar Cebrián

erer=https\%3A\%2F\%2Fwww.google.com\%2F

Wintour, P. (2019, September 17). Trump: EU must take back 800 Isis fighters captured in Syria. Retrieved August 2020, from The Guardian: https://www.theguardian.com/world/2019/feb/17/islamic-state-isis-baghuztrump-calls-on-european-allies-to-take-800-fighters-captured-in-syria

UN. (2020, August 13). Deaths of children in northeast Syria 'could have been averted': UNICEF. Retrieved August 2020, from UN News: https://news.un.org/en/story/2020/08/1070122

UN Office on Drugs and Crime. (2020). Handbook on Restorative Justice Programmes. Vienna: United Nations. 